\title{
INTRODUCTION: THE LOTUS SUTRA AND PROCESS THOUGHT
}

Seven of the articles in this issue were originally contributions to a small conference devoted to the theme "The Lotus Sutra and Process Thought." Since 1994, the Buddhist organization Rissho Kosei-kai has sponsored a series of international conferences on the Lotus Sutra, all held in the beautiful mountain setting of northeastern Japan at a small conference center called "Bandaiso." Themes have varied from year to year, and the conference held in July of 2000 was the first devoted to comparing the thought of the Lotus Sutra with a school of philosophy. Six scholars from the United States and five from Japan participated, all of whom wrote articles for the conference. Eight of those articles have been revised for inclusion in this issue of the Journal of Chinese Philosophy.

Of the seven contributors, three are both Buddhist scholars and philosophers, two are philosophers, and two are Christian theologians. All seven are familiar with process thought, although they are rooted in somewhat different traditions, demonstrating that process thought itself is far from being a monolithic point of view. Familiarity with the Lotus Sutra varies enormously among the group; some read the Lotus Sutra for the first time in preparation for this conference, whereas others have studied it over many years.

Several conference participants expressed the conviction that process thought, especially as that has been articulated by Alfred North Whitehead, Charles Hartshorne, and John Dewey and their intellectual descendants, can provide an especially interesting and useful way of interpreting and giving philosophical statement to themes in the Lotus Sutra. It can, in a sense, illumine what is taught in the Sutra, giving greater credence to many of its ideas. But it may also be the case that the Lotus Sutra will contribute to further developments in process philosophy and theology.

My own work of recent years has focused on this relationship, and this is developed in the article appearing here. I try to show senses in which both process thought and the Lotus Sutra are integrating philosophies, harmonizing what otherwise might be seen as disparate factors of human experience: They are philosophies of becoming, in which all

Journal of Chinese Philosophy 28:4 (December 2001) 355-356

(C) 2001 Journal of Chinese Philosophy 
actuality is understood to be a dynamic process; they are philosophies of creativity, making creativity and freedom an important character of all reality; and they are universalist, in the sense that they understand all living beings to be capable of redemption, resulting in an ethics of universal respect and compassion.

Joseph Grange's article can be seen as expanding on the integration theme by developing further, among other things, the ways in which dualism is overcome in these views, especially through use of what appears in the Lotus Sutra as "skillful means."

Steve Odin focuses on the interrelational vision of reality that is found especially in the T'ien-t'ai doctrine of ichinen sanzen-three thousand worlds in one moment - in which every event is a microscopic version of the macroscopic whole. Odin then shows how this vision is related to peace and compassion in both the Lotus Sutra and Whitehead's philosophy.

Brook Zyporyn contrasts the relationship between Whitehead's thoroughly atomistic view of process, in which agency is found only in momentary actualities, and the T'ien-t'ai Buddhist idea from the Lotus Sutra of "opening the provisional to reveal the real," in which every actuality is "interfused" with every other. The T'ien-t'ai view provides a basis for criticizing Whitehead's views of "eternal objects" and God.

Marjorie Hewitt Suchocki compares God in process thought with the Buddha of the Lotus Sutra and suggests that both may be expressions of what the Sutra calls "skillful means."

Warren G. Frisina's article looks at the relation of thought and action in the thought of John Dewey, neo-Confucian thinkers, and the Lotus Sutra, concluding that knowledge and action are to be understood as an inseparable unity in which humans respond to an always-changing world.

Chung-Ying Cheng traces the development of the Buddhist truth of the middle as an affirmation of "the reality of reality," thus being consonant with process notions of creativity and the importance it gives to everyday life. But, claims Cheng, it is only in Daoist writings, particularly the Yijing, that a full cosmological account of creativity is to be found.

GENE REEVES

Tokyo

March 2001

\section{ENDNOTE}

1. A fuller account of the conference can be found in Philip E. Devenish's "The Lotus Sutra Compared with Process Philosophy," Dharma World 27 (Nov./Dec. 2000): 21-23. 